\title{
奴隷貿易にジェンダーの視点を クロスオーバーさせる
}

井野瀬久美惠

ヨーロッパ、アフリカ、(南北) アメリカと いう三つの大陸を大西洋上で結んだことから 「三角貿易」の名で知られる奴隷貿易。この社 会経済システムを、日本の世界史教科書はどの ように記述しているのだろうか。いや、そもそ も、奴隷貿易が今の歴史教育においてなぜ問題 なのだろうか。

実は今から 3 年前の 2007 年は、イギリス議会 で奴隷貿易廃止法が成立して 200 年目という節 目にあたり、イギリス各地やかつてこの貿易と 関わったアフリカ、カリブ海域、アメリカなど では、この出来事を顕彰するさまざまなイベン トが行われた。この歴史的出来事に「深い遺憾 の意」を示しつつも、微妙に「謝罪」を回避し たブレア首相の発言が物議を醸し、歴史におけ る和解や謝罪をめぐる議論も紛紏した。そのな かでイギリスでは、2008年の新学期以降、奴隷 貿易とその廃止のプロセスを教えることが義務 教育課程（Key Stage 3、11～14歳）で必修化 された。次代を担う若者に今何を伝えるべきか 一歴史教科書の重要な使命を再認識させる動 きであろう。

すでにそれ以前、奴隷貿易および奴隷制度を 「人道に反する罪」と明言したダーバンでの国 連 - 反人種差別世界会議（2001）以来、「奴隷 貿易の記憶」はグローバルに共有される「現代 の問題」となっていた。歴史と記憶をめぐって 似たような問題を抱える日本だが、「奴隷貿易 の記憶」が「今」と関連づけて話題になること
はほとんどなかった。

\section{奴隷貿易の記憶}

現在日本で使用されている高校世界史の教 科書において、奴隷貿易および奴隷制度の記述 に関して注目されるのは、質・量ともに教科書 間格差がきわめて大きいことである。その原因 のひとつは、奴隷貿易を(いわば)「単体」でヨー ロッパの発展の一コマとして扱うか、この社会 経済システムを近代以降のアフリカの低開発 や（移民を含む）人の動きといった大きな流れ のなかに位置づけて考えるか、にあるように思 われる。

とはいえ、後者の場合でも、奴隷貿易（およ び奴隷制度）廃止のプロセスで奴隷自身が示し た「抵抗」の多様な形や彼らの主体性への言及 はほとんど見られない。それゆえに、今年 1 月 の大地震で甚大な犠牲者を出したハイチの「独 立」についても、1791年にこの島の奴隷たち が解放をめざして反乱に立ち上がった 8 月 23 日 が、ユネスコによって「奴隷貿易とその廃止の 国際記念日」に制定されていること一一言い換 えれば、この奴隷反乱が「今想い起こすべき記 憶」であるとの認識は欠落している。こうした 状況では、奴隷貿易に関するジェンダーの視点 など望むべくもないだろう。

まずは、奴隷貿易（および奴隷制度）とその 廃止というテーマが、すでに過ぎ去った出来 
事ではなく、われわれが生きる現代世界と深く 関わっていることを意識する必要がある。その うえで、この問題にジェンダーの視点をクロス オーバーさせると、そこには何が浮かびあがっ てくるだろうか。

\section{ジェンダーの視点を重ねる}

一つは、大西洋を渡る奴隷貿易が、三角形の 各々の頂点、ヨーロッパ、アフリカ、南北アメ リカにおけるジェンダー・アンバランスの上に 成立していたことである。当時のカリブ海域や アメリカ、ブラジルなどのプランテーションが 求めたのは、もっぱら、砂糖や綿花栽培の過酷 な労働に耐えうる男性労働力であった。一方、 アフリカ社会は、家内労働はじめ、多種多様の 労働が女性に任されており、女性の流出は避け たかった。加えて、奴隷人口動態をめぐる近年 の研究は、多産をよしとするアフリカ社会から 「子どもを産めない女性たちが奴隷として売ら れた」ことを明らかにしている。こうした意味 では、奴隷貿易は、ヨーロッパとアフリカの「男 たちの共犯関係」の上に構築されたシステムで もあるのだ。

二つ目に、奴隷貿易廃止のプロセスに着目す れば、イギリスではもっぱら女性が砂糖ボイ コット運動の担い手であったこと、それが女性 自身の権利を主張するその後のフェミニズム 運動へとつながったことが見えてくる。

\section{PROFILE}

井野瀬久美惠

(いのせ くみえ)

日本学術会議連携会員、甲南大学文 学部英語英米文学科教授

専門：イギリス近代史・大英帝国史

さらに三つ目として、奴隷自身の主体性に目 を向ければ、「黒人女性は总惰で性的にだらし ない」という白人奴隷主の偏見にも別の意味が 読み取れることを指摘しておきたい。「奴隷の 子は奴隷主の所有物」だった当時、奴隷にされ た女性たちは、郢胎に加えて、「嬰児殺し」と いう、今のわれわれにはショッキングな方法で、 奴隷の再生産を阻止しょうとしていた。それは、 「生後 9 日目までの嬰児は人間ではない」とす る当時のアフリカ文化に依拠した行動であり、 それゆえに、(少なくとも彼女たちにとって) それは「犯罪」とは認識されていなかった。堕 胎や嬰児殺しは、「奴隷主の所有物」でしかな いわが子の将来を悲観した母性の主体的な抵 抗の形だったのである。

\section{ジェンダーの視点を武器として}

このように、ジェンダーの視点を奴隷貿易・ 奴隷制度の問題にクロスオーバーすれば、ヨー ロッパ目線で作られた人種偏見を超えて、奴隷 の出身地であるアフリカ各地固有の文化やモ ラルなども見えやすくなるだろう。と同時に、 
奴隷貿易の問題をジェンダーの視点から再考 することは、人身売買はじめ、ケアワークやセッ クス産業における女性のグローバルな移動、そ れとつながる現代日本社会の問題を考えるこ とにもなるのである。

われわれが生きる今の世界はどのようにし て到来したのか。歴史は、過去と現在との不断 の対話によって構成されている。21世紀の今 なお、奴隷貿易の問題はその格好の素材なので ある。そして、ジェンダーの視点は、その対話 に絡みつく偏見を断つ“武器”でもある。 